\title{
PROGRAM PEMBELAJARAN BAHASA ARAB DI SMP PLUS AL-AQSHA JATINANGOR SUMEDANG
}

\author{
Ulfah Fauziyah Rahmah \\ Pascasarjana UIN Sunan Gunung Djati Bandung \\ Jl. Cimencrang, Gedebage, Kota Bandung, Jawa Barat 40292 \\ email:ulfahfauziyahr@gmail.com
}

\begin{abstract}
Al-Aqsa Middle School is a boarding school-based junior high school, which requires all students to stay in a dormitory for three years and speak Arabic and English. Al-Aqsa Middle School graduates can become individuals who are familiar with foreign languages based on language learning routines. This study tries to reveal the Arabic learning system so that students can get used to speaking Arabic. This research is qualitative research using descriptive methods. The code collection techniques used in this study were observation, interviews, and documentation. The purpose of this study is to describe the implementation of learning the Arabic language, knowing the supporting and inhibiting factors, and expressing the abilities of their students. The results of this study indicate that: 1) the implementation of linguistic programs carried out by the AlAqsha Middle School language development institution consisting of planning, organizing, implementing, controlling, and evaluating has not been maximally achieved. 2) Factors supporting the implementation of this linguistic program are those of the language instructors in language. The drawing factor is the freedom of communication used between students and traders. 3) The ability of the Arabic language skills of students at Al Aqsha Plus Middle School is not good enough because the program implementation has not been maximized.
\end{abstract}

Keywords: Learning Arabic; Language Skills; Boarding School.

\begin{abstract}
Abstrak
SMP Plus Al-Aqsha merupakan sekolah menengah pertama berbasis pesantren, yang mewajibkan seluruh siswa-siswinya untuk tinggal di asrama selama 3 tahun dan berbicara dengan bahasa Arab dan Inggris. Lulusan SMP Plus Al-Aqsha ini dapat menjadi pribadi yang terbiasa dengan berbahasa asing, berdasarkan rutinitas pembelajaran bahasa tersebut penelitian ini mencoba untuk mengungkapkan sistem pembelajaran bahasa Arab sehingga peserta didiknya dapat terbiasa berbicara bahasa Arab. Penelitian ini berjenis penelitian kualitatif dengan menggunakan metode deskriptif. Observasi, wawancara, dan dokumentasi
\end{abstract}


merupakan teknik pengumpulan data yang digunakan. Tujuan penelitian ini adalah untuk menggambarkan pelaksanaan pembelajaran bahasa Arab, mengetahui faktor pendukung dan penghambat, dan mengungkapkan kemampuan peserta didiknya. Hasil dari penelitian ini menunjukan bahwa: 1) Pelaksanaan program kebahasaan yang dilakukan oleh lembaga pengembangan bahasa terdiri dari perencanaan, pengorganisasian, pelaksanaan, kontrol, dan evaluasi belum maksimal dilaksanakan. 2) Faktor pendukung pelaksanaan program kebahasaan ini adalah disiplinnya para pengajar bahasa dalam berbahasa, faktor penghambatnya adalah bebasnya bahasa yang digunakan antara siswa dengan para pedagang. 3) Kemampuan keterampilan berbahasa Arab siswa belum cukup baik dikarena pelaksanaan program belumlah maksimal.

Kata Kunci: Pembelajaran Bahasa Arab; Keterampilan Berbahasa;

\section{Pesantren.}

\section{A. Pendahuluan}

Pembelajaran merupakan suatu proses pendidikan seorang pendidik dengan peserta didiknya melalui interaksi yang baik di dalam sebuah lingkungan belajar dengan sumber belajar yang jelas. Bertambahnya ilmu dan pengetahuan peserta didik merupakan bantuan yang diberikan pendidik dalam proses pembelajaran, berikut juga dalam hal penguasaan kemahiran, tabiat, serta pembentukan sikap dan kepercayaan pada peserta didik. Dengan demikian, pembelajaran merupakan bantuan yang diberikan kepada peserta didik untuk dapat belajar dengan baik.

Bahasa Arab merupakan salah satu materi bahan ajar dalam proses pendidikan, maka pembelajaran bahasa Arab diperlukan untuk berbagai kepentingan membuka ilmu-ilmu lainnya. Dengan demikian pembelajaran bahasa Arab perlu dipelajari agar peserta didik dapat berkomunikasi dengan baik dan benar dengan sesamanya sehingga tercipta lingkungan berbahasa Arab yang baik untuk tumbuh dan berkembangnya peserta didik. Maka sekurang-kurangnya terdapat empat keterampilan yang perlu dikuasai peserta didik dalam pembelajaran bahasa Arab, di antaranya adalah mahārah istimā' (keterampilan menyimak), mahārah kalām (keterampilan berbicara), mahārah qirāh (keterampilan membaca), dan mahārah kitābah (keterampilan menulis). Keterampilan membaca dan menyimak dikategorikan dalam keterampilan reseptif atau mahārah al-istiqbāliyah, sedangkan keterampilan berbicara dan menulis dikategorikan ke dalam keterampilan produktif atau mahärah alintājiyah. Kesuksesan pembelajaran bahasa Arab terjadi dimana siswa bisa menguasai empat keterampilan bahasa tersebut. ${ }^{1}$

\footnotetext{
${ }^{1}$ Acep Hermawan, Metodologi Pembelajaran Bahasa Arab (Bandung: Remaja
} Rosdakarya, 2011), h. 129. 
Sebagaimana penjelasan tentang keterampilan dalam berbahasa tersebut maka dari empat kategori kecakapan dalam pembelajaran bahasa Arab, yaitu maharah istima', kalam, qiraah, kitabah. Berikut ini pendapat Abdurrahman Ibrahim Al-Fauzan tentang keterampilan menyimak adalah keterampilan pertama yang dimiliki seorang anak dalam memperoleh bahasa ibunya. Begitu juga seorang pelajar bahasa asing melewatinya. Telah diketahui bahwa siapa pun yang tidak dapat mendengar, berbicara, dan tuli sejak kecil adalah orang bisu. Karena itu, lebih mungkin bahwa mereka yang kehilangan kedua indera tersebut harus dalam suatu program pendidikan khusus (bahasa isyarat). ${ }^{2}$ Tujuan Istima' Muassa' adalah untuk mendengarkan teks-teks baru dalam batas-batas tingkat, dan itu mungkin dengan mendengarkan kembali bahanbahan yang sebelumnya disajikan kepada siswa, tetapi mereka sekarang disajikan dalam bentuk baru atau situasi yang baru.

Selanjutnya adalah keterampilan berbicara atau mahārah kalām, pada dasarnya keterampilan ini merupakan murni dari kemampuan peserta didik dalam memproduksi rangkaian kosakata yang diketahuinya menjadi sebuah kalimat yang terucap.

Kemudian selanjutnya keterampilan membaca adalah keterampilan membunyikan simbol-simbol lambang bunyi yang bersifat arbitrer, selanjutnya dari membunyikan lambang-lambang bunyi tersebut dapat dipahami suatu makna yang akan berkesinambungan dengan makna kata yang lainnya sehingga dari kecakapan membaca ini siswa mendapatkan pemahaman makna menyeluruh dalam sebuah kalimat, paragraf atau bahkan dalam sebuah cerita.

Keterampilan produktif yang selanjutnya setelah keterampilan berbicara adalah keterampilan menulis, keterampilan ini murni merupakan kemampuan peserta didik dalam merangkai kata demi kata untuk menjadi sebuah kalimat yang bermakna dan untuk merangkai setiap kalimat menjadi sebuah paragraf yang apik dibutuhkan ilmu ilmu dasar yang perlu dikuasai peserta didik, yaitu nahwu dan sharaf. ${ }^{3}$

SMP Plus Al Aqsha merupakan sekolah menengah pertama berbasis pesantren, yang mewajibkan seluruh siswa siswi untuk tinggal di asrama selama 3 tahun. Pembelajaran bahasa merupakan salah satu program unggulan sekolah khususnya dalam pembelajaran bahasa Arab dan bahasa Inggris. Sebagai skala prioritas pembelajaran, sekolah memiliki beberapa program kegiatan yang menunjang untuk peningkatan bahasa. Program-program tersebut dirumuskan oleh satu bagian yang bernama unit bahasa Al-Aqsha, sehingga bagian ini bertanggung jawab atas perkembangan bahasa di

\footnotetext{
${ }^{2}$ Abdurrahman Ibrahim Al-Fauzan, Idha'at li Mu'allimi Lughah Arabiyah li Ghair Nathiqin Biha (Riyadh: Al-Arabiyyah Li Al-Jami', 2011), h. 67.

${ }^{3}$ Hermawan, Metodologi Pembelajaran Bahasa Arab, h. 135.
} 
lingkungan SMP Plus Al-Aqsha. Pembelajaran bahasa Arab di SMP Plus ALAqsha ini lebih menekankan pada penguasaan ilmu bahasa yang mendasar agar kemudian dapat diaplikasikan dalam berbagai jenis keterampilan berbahasa lainnya seperti menyimak, berbicara, membaca dan menulis. Diharapkan para siswa sebagai peserta didik dapat mampu menerjemahkan juga mengaplikasikan empat keterampilan berbahasa tersebut dalam kehidupan sehari-harinya di asrama. Program pembelajaran bahasa Arab di SMP Plus Al Aqsha memiliki dua kurikulum yang berbeda, yaitu pembelajaran formal di dalam kelas yang menggunakan kurikulum sekolah dan pembelajaran di luar kelas yang dipimpin di bawah unit bahasa dengan menggunakan program-program pesantren.

Pada pembelajaran di SMP Plus Al-Aqsha, program pengajaran bahasa Arab berfokus pada tujuan akademik. Seperti diketahui bahwa pengajaran Bahasa Arab untuk penutur non Arab umumnya dibagi menjadi dua jenis yaitu: Bahasa Arab untuk kehidupan (Arabic language for life), yang merupakan program belajar bahasa Arab hanya dimaksudkan untuk berkomunikasi dengan bahasa Arab di berbagai situasi kehidupan. Sedangkan tipe kedua adalah program bahasa Arab untuk keperluan khusus, termasuk di dalamnya adalah bahasa Arab untuk tujuan akademik (Arabic for academic purposes). ${ }^{4}$

Adapun faktor-faktor yang mempengaruhi belum proporsionalnya pengajaran bahasa Arab di pondok pesantren adalah: 1) Kebutuhan masyarakat terhadap keilmuan alumni santri. 2) Tujuan pengajaran bahasa Arab yang utama untuk memahami kitab kuning. 3) Padatnya jadwal pengajaran materimateri inti pondok pesantren. ${ }^{5}$ Sedangkan dalam penerapan manajemen pengorganisasian markaz bahasa Arab Darul Lughah Waddirasat Islamiyah mengadopsi tipe organisasi lini. Organisasi ini menerapkan pengelompokan program berdasarkan jenjang masing-masing tingkatan. Dalam penyerahan wewenang dan tanggung jawab didasarkan pada tugas pokok yang terdapat dalam struktur organisasi. Jadi, para anggota organisasi tidak sewenangwenang dalam menjalankan tugas pokoknya. Penyerahan tugas ini tidak serta merta diberikan kepada sembarang orang, akan tetapi melalui sistem kualifikasi yang ketat. ${ }^{6}$

${ }^{4}$ Ahmad Fatoni, "Arabic Learning for Academic Purposes," Izdihar : Journal of Arabic Language Teaching, Linguistics, and Literature 2, no. 2 (2019): 149-64, https://doi.org/10.22219/jiz.v2i2.10096.

${ }^{5}$ J. Sutarjo dan Albarra Sarbaini, "Proporsi Pengajaran Bahasa Arab Di Pondok Pesantren Ditinjau Dari Aspek Tipologi," An Nabighoh: Jurnal Pendidikan Dan Pembelajaran Bahasa Arab 21, no. 01 (2019): 1-19, https://doi.org/10.32332/an-nabighoh.v21i01.1254.

${ }^{6}$ Islahel Umam, Moh Hasin, dan Zakiyah Arifa, "Manajemen Pengorganisasian Program Kursus Markaz Bahasa Arab Darul Lughah Waddirasat Islamiyah," An Nabighoh: Jurnal Pendidikan Dan Pembelajaran Bahasa Arab 21, no. 01 (2019): 43-60, https://doi.org/10.32332/an-nabighoh.v21i01.1376. 
Adapun pembelajaran kebahasaan di SMP Plus Al Aqsha ini memiliki program yang terstruktur. Pada program kegiatan harian siswa diwajibkan mengikuti pembelajaran mulai dari pemberian kosakata bahasa Arab (al mufradat), penyampaian kata mutiara bahasa Arab (al uslub), serta mengulas kembali semua pembelajaran yang telah mereka ikuti secara terpimpin setiap hari sebelum tidur. Selain kegiatan harian, terdapat juga program kegiatan mingguan, bulanan, dan tahunan yang meliputi muhadatsah, firqotullughoh al aribiyah, membuat mading bahasa, kompetisi bahasa, dan seminar kebahasaan.

Berdasarkan latar belakang penelitian tersebut, penelitian ini dianggap perlu untuk dilakukan untuk dapat mengetahui dan mengungkapkan mekanisme program pembelajaran bahasa Arab di SMP Plus Al-Aqsha Cibeusi Jatinangor kabupaten Sumedang.

Pada penelitian ini didukung oleh beberapa penelitian-penelitian terdahulu. Adapun penelitian relevan yang berkaitan dengan penelitian ini yaitu di antaranya sebagai berikut:

1) Artikel jurnal dengan judul "Program Pembelajaran Bahasa Arab di Madrasah Aliyah" yang ditulis oleh Yanuar Rizal, Adelina Hasyim, dan Riswandi Riswandi. Tujuan penelitian tersebut yaitu mendeskripsikan dan merekomendasikan hasil penelitian terhadap program pembelajaran bahasa Arab di MAN I Bandar Lampung yang sesuai dengan Standar Proses, Standar Isi, dan Standar Penilaian. Sedangkan hasil penelitian menyatakan bahwa program pembelajaran bahasa Arab di MAN I Bandar Lampung Kelas $\mathrm{X}$ belum memenuhi standar proses terutama terkait dengan perencanaan pembelajaran yang dibuat tidak sesuai dengan kebutuhan peserta didik. Standar isi belum mencapai indikator perencanaan, dan kurangnya standar penilaian pada instrumen penilaian. ${ }^{7}$

2) Tesis yang ditulis oleh Mohammad Amar Shodiq dengan judul "Analisis Kebijakan Pengembangan Program Pembelajaran Bahasa Arab di Boarding School Madrasah Aliyah Negeri Ciawigebang Kuningan Jawa Barat". Penelitian ini menggunakan pendekatan kombinasi model/ desain concurrent embedded. Penelitian ini bertujuan untuk mengetahui proses pembuatan kebijakan pengembangan program pembelajaran bahasa Arab. Hasil penelitian ini menunjukkan bahwa: (1) Latar belakang perumusan masalah pembuatan kebijakan pengembangan program pembelajaran bahasa Arab meliputi adanya permasalahan di lingkungan sekolah. (2) Berbagai kebijakan pengembangan program pendidikan bahasa Arab. (3) Pendekatan sintetis riset dan praktek kiranya sejalan dengan apa yang diadopsi oleh madrasah dalam melakukan pemantauan hasil

\footnotetext{
${ }^{7}$ Yanuar Rizal, Adelina Hasyim, dan Riswandi Riswandi, “Program Pembelajaran Bahasa Arab Di Madrasah Aliyah," Jurnal Teknologi Informasi Komunikasi Pendidikan 5, no. 1 (2017), http://jurnal.fkip.unila.ac.id/index.php/JTP/article/view/11986.
} 
kebijakannya. (4) Hasil komparasi terhadap hasil belajar yang mengikuti program boarding dan tidak mengikuti program boarding, menunjukkan nilai signifikansi. Hal tersebut membuktikan bahwa penerapan kebijakan pengembangan program pembelajaran bahasa Arab efektif diterapkan. ${ }^{8}$

3) Skripsi karya Farkhatul Isqolaliyah dengan judul "Pembelajaran Bahasa Arab di THGB Pondok Pesantren Majma'al Bahrain Siddiqiyah Ploso Jombang”. Penelitian ini bertujuan untuk mendeskripsikan pembelajaran bahasa Arab di THGB Majma'al Bahrain Siddiqiyah Ploso Jombang. Penelitian ini menggunakan rancangan deskriptif kualitatif. Teknik pengumpulan data adalah observasi, wawancara, angket dan dokumen. Hasil penelitian menunjukkan bahwa pembelajaran bahasa Arab di THGB sebagai berikut: (1) Metode yang digunakan adalah metode eklektik berupa penggabungan antara metode membaca, metode komunikatif, dan metode qowaid terjemah. (2) Bahan ajar yang digunakan yaitu buku LKS terbitan PT. Temprina Media Grafika dan buku panduan dari THGB. (3) Media yang digunakan guru adalah buku pegangan dan papan tulis (4) Evaluasi bahasa Arab yang dilakukan adalah tes tulis dan tes lisan. ${ }^{9}$

\section{B. Hasil dan Pembahasan}

1. Pelaksanaan Program Pembelajaran Bahasa Arab di SMP Plus AlAqsha

Pelaksanaan program kerja apa pun tentu perlu diawali dengan perencanaan yang matang, begitu pun dengan lembaga yang khusus memiliki tujuan untuk pengembangan bahasa asing. Maka dari itu, lembaga pengembangan bahasa ini dimulai dari perencanaan yang matang sebagaimana yang diungkapkan oleh ketuanya berikut ini:

1) Persiapan matang sebelum menyampaikan kepada seluruh santriwan maupun santriwati, menentukan Jenis kegiatan bahasa, menentukan waktu, tempat kegiatan bahasa, mempersiapkan semua keperluan bahasa, menentukan tugas masing-masing bagian bahasa.

2) Pelaksanaan Kegiatan

3) Evaluasi, cek monitoring dan kontrol. Setiap selesai kegiatan bahasa dilakukan evaluasi dan Monitoring yang bertujuan menghindari dari kesalahan dalam pelaksanaan program bahasa selanjutnya.

\footnotetext{
${ }^{8}$ Mohammad Amar Shodiq, "Analisis Kebijakan Pengembangan Program Pembelajaran Bahasa Arab Di Boarding School Madrasah Aliyah Negeri Ciawigebang Kuningan Jawa Barat" (Thesis, Yogyakarta, UIN Sunan Kalijaga, 2016), http://digilib.uinsuka.ac.id/22645/.

${ }^{9}$ Farkha Isqolaliyah, "Pembelajaran Bahasa Arab di Tarbiyyah Hifdhul Ghulam Wal Banat (THGB) Pondok Pesantren 'Majma'al Bahrain' Siddiqiyah Ploso Jombang," Skripsi Universitas Negeri Malang 0, no. 0 (26 September 2012), http://karyailmiah.um.ac.id/index.php/sastra-arab/article/view/22507.
} 
Di SMP Plus Al-Aqsha Jatinangor ini seluruh santriwan maupun santriwati wajib berbahasa resmi dan mematuhi aturan yang sudah ditetapkan oleh pondok khususnya dalam berbahasa, yaitu bahasa Arab dan Inggris. Jika terdapat santri yang melanggar aturan bahasa maka akan dihukum, dan sanksinya sebagaimana diungkapkan pengajar:

1) Hukuman di tempat bagian bahasa dan asatidz maupun asatidzat.

2) Mahkamah bahasa bagi para pelanggar bahasa baik putra maupun putri.

3) Peringatan apabila melanggar bahasa lebih dari tiga kali.

4) Memakai rompi dan kerudung khusus bagi pelanggar.

Tidak hanya mendapatkan sanksi ketika melanggar peraturan, lembaga pengembangan bahasa di pondok ini pun memberikan penghargaan kepada mereka yang berprestasi. Dan reward untuk siswa yang berprestasi di antaranya adalah 1) Menjadi utusan pondok dalam event event penting bahasa. 2) Mendapatkan sertifikat penghargaan.

Adapun dengan program evaluasi yang dilaksanakan oleh lembaga pengembangan bahasa pondok modern Al-Aqsha Jatinangor ini adalah dengan diadakannya ujian 2 kali dalam satu semester. Pendekatan Metode Saintifik yang digunakan dalam pengembangan bahasa siswa di SMP Plus Al-Aqsha ini 1) Berpusat pada santriwan dan santriwati atau peserta didik. 2) membentuk kemampuan santri dalam menyelesaikan suatu masalah. 3) Terciptanya kondisi belajar dimana siswa merasa bahwa belajar itu suatu kebutuhan. 4) Mengembangkan karakter santri.

Dalam program pengembangan bahasa santri, khususnya dalam bahasa arab terfokus pada kecakapan mendengar, membaca, berbicara, dan menulis. Tujuan Maharah Kalam atau kecakapan berbicara ini adalah 1) untuk membuat peserta didik terbiasa berbicara dengan cara mengembangkan kosakata-kosakata yang telah diberikan dan dikuasai dalam bentuk percakapan yang wajar dan menyenangkan bagi siswa sebagai peserta didik. 2) fasंahah al-kalām yaitu kejelasan pelafalan dalam berbicara sehingga peserta didik dapat mengeluarkan kalimat dari lisannya dengan artikulasi diksi yang jelas. 3) bertanggung jawab secara penuh atas segala sesuatu yang disampaikan dan berbicara secara tepat. Adapun dengan bahan ajar yang digunakan adalah buku, modul, berita, film, video dan lain sebagainya.

Kemudian tujuan mahārah qirāah adalah 1) siswa dapat mengenali naskah-naskah berbahasa Arab dengan baik. 2) menggunakan kosakata yang telah diberikan dalam membaca dan mengambil makna dari bacaan tersebut. 3) Memahami makna bahasa Arab dan Inggris. 4) memahami Hubungan dalam kalimat, antar kalimat, antar paragraf bahasa Arab maupun Inggris. Adapun dengan bahan ajar yang digunakan adalah buku, modul, berita, film, video dan lain sebagainya. 
Pada dasarnya, semua kecakapan dalam pembelajaran di tingkat SMP hanya sebatas mengetahui dasar dasarnya saja, itulah yang diungkapkan oleh ketua lembaga pengembangan bahasa. Ada pun dengan tujuan maharah kitabah adalah 1) Agar siswa sebagai peserta didik terbiasa dengan menulis bahasa Arab dengan baik dan benar. 2) Melatih siswa sebagai peserta didik agar menggunakan kosakata yang telah diberikan untuk digunakan dalam media tulisan. 3) Agar siswa sebagai peserta didik dapat dengan cermat menulis rangkaian kosakata bahasa Arab yang telah diberikan. 4) Untuk melatih siswa sebagai peserta didik dalam membuat sistematika berpikir sehingga memiliki pemikiran yang logis dan sistematis dalam menulis dengan cara membuat dan merangkai kalimat menjadi paragraf dan paragraf menjadi sebuah tulisan yang menarik dan bermakna untuk dibaca orang lain. Adapun dengan bahan ajar yang digunakan adalah buku, modul, berita, film, video dan lainnya.

Di samping pelaksanaan program, terdapat pengajar yang menjadi ujung tombak keberhasilan program lembaga pengembangan bahasa. Dan dari hasil wawancara dengan salah satu pengajar serta pengamatan pada silabus materi pembelajaran tersebut, dapat dinyatakan bahwa lembaga kebahasaan berperan sebagai tombak utama penggerak bahasa di lingkungan pondok tentunya selain harus menjadi uswah hasanah dalam berbahasa. Lembaga ini juga harus bisa membuat terobosan-terobosan baru yang bisa menjadikan lingkungan pondok menjadi lingkungan berbahasa yang dilaksanakan dalam bentuk program kerja harian, mingguan, dan tahunan. Pergerakan ini diharapkan dapat selalu memotivasi santri dan seluruh civitas Pondok Modern Al Aqsha untuk terus mengasah dan meningkatkan kebahasaannya. Dan hal terpenting yaitu evaluasi dan pengawasan pada program yang telah dibuat.

Berdasarkan pembahasan tersebut dapat disimpulkan bahwa pelaksanaan program kebahasaan yang dilakukan oleh lembaga pengembangan bahasa SMP Plus Al-Aqsha terdiri dari perencanaan, pengorganisasian, pelaksanaan, kontrol, dan evaluasi. Perencanaan program dilaksanakan secara bersama pada awal tahun pembelajaran, pengorganisasian dilaksanakan secara kondisional berdasarkan kebutuhan program tertentu, pelaksanaan program dilaksanakan sesuai perencanaan dan pengorganisasiannya, kontrol dilakukan setiap saat oleh petugas yang ditugaskan pada kegiatan tertentu, dan evaluasi program dilaksanakan melalui ujian kebahasaan bulanan, dan tahunan.

\section{Faktor Pendukung keberhasilan Program}

Berdasarkan keterangan dari ketua lembaga pengembangan bahasa bahwa faktor internal pendukung keberhasilan program-program pengembangan bahasa adalah: 1) Uswah Hasanah. 2) Mewajibkan seluruh dewan guru untuk memberikan contoh dalam berbahasa baik 
Arab maupun Inggris. 3) Penekanan Bahasa baik di kelas maupun di luar kelas. 4) Mewajibkan santri dan pengurus asrama untuk melakukan muroja'ah atau pengulangan hafalan sebelum tidur. 5) Mewajibkan kepada seluruh pengurus organisasi untuk wajib berbahasa resmi.

Adapun faktor eksternal pendukungnya adalah 1) Mewajibkan kepada seluruh guru yang tinggal di luar pondok pesantren untuk memberikan uswah yang baik dan berbicara resmi baik Arab maupun Inggris. Apabila tidak mampu, maka menggunakan bahasa Indonesia dan tidak menggunakan bahasa daerah. 2) Mendatangkan ahli bahasa baik Arab maupun Inggris. 3) Mengajak wali santri pondok modern Al-Aqsha untuk menggunakan bahasa Indonesia ketika di dalam pondok.

Dengan demikian dapat disimpulkan bahwa faktor pendukung berhasilnya program pengembangan bahasa terdiri dari faktor internal dan eksternal. Faktor Pendukung internalnya terdiri dari 1) Suri tauladan yang baik dari para pengajarnya. 2) Program yang tepat untuk siswa. 3) Peraturan kebahasaan yang telah menjadi kebiasaan. Adapun faktor eksternal pendukungnya adalah sarana dan prasarana yang memadai.

\section{Faktor Penghambat Program}

Berdasarkan hasil wawancara dengan salah satu pengajar, yang menyatakan bahwa faktor internal penghambat: 1) Belum adanya uswah dan contoh dalam berbahasa. 2) Masih banyak didapatkan yang berbicara bahasa daerah baik asatidz ataupun ustadzah dan bapak ibu guru. 3) Banyak dari pengurus asrama maupun pengurus OPPMA yang tidak berbahasa resmi bahkan berbicara bahasa daerah. 4) Bercampurnya antara santri dengan pedagang maupun karyawan pondok sehingga banyak ditemukan berbicara bahasa daerah. 5) Sulit untuk menciptakan miliu bahasa yang baik dan kondusif.

Kemudian selain faktor internal, terdapat faktor eksternal penghambatnya sebagaimana berikut: 1) Bercampurnya antara santri dengan pedagang sekitar pondok sehingga sering terdengar berbahasa Sunda yang dimana bisa dikatakan bahasa kasar. 2) Faktor lingkungan di luar pondok yang kurang mendukung. 3) Banyak dari wali santri yang berbicara bahasa daerah ketika mengunjungi anak anaknya.

\section{Keberhasilan Pelaksanaan Program}

Maharah Kitabah Santri :1) Masih sangat jauh dari kata mampu bahkan bisa dikatakan belum bisa. 2) Santri belum mampu menulis bahasa Arab yang baik dan benar. 3) Santri sebagai peserta didik belum mampu mengungkapkan dan mendeskripsikan sesuatu baik yang dia lihat atau alami dengan bahasa Arab yang baik dan benar. 4) Santri sebagai peserta didik masih belum mampu memilih kosakata yang baik sehingga mereka masih merasa kebingungan untuk dapat merangkai kata menjadi sebuah kalimat yang bermakna. 5) Santri atau siswa sebagai peserta didik 
masih belum mampu menuliskan kosakata bahasa Arab yang diucapkan guru dengan baik dan benar karena belum menguasai ilmu-ilmu dasar dengan baik.

Percakapan atau muhādasंah yaitu cara menyajikan bahasa dalam pelajaran Bahasa Arab. Melalui percakapan, dalam percakapan itu dapat terjadi antara guru dan murid dan antara murid dengan murid, sambil menambah dan terus memperkaya perbendaharaan kata-kata (vocabulary) yang semakin banyak. ${ }^{10}$ Berdasarkan pengakuan para pendidik yang menyatakan bahwa maharah kalam Santri sebagaimana berikut: 1) Santri belum mampu mengenali kata dan kalimat dalam bahasa Arab. 2) Santri belum mampu menceritakan kembali isi bacaan khususnya dalam pelajaran dirasah islamiyah. 3) Santri belum mampu mengenali naskah tulisan bahasa yang baik dan benar. 4) Santri belum mampu memaknai dan menggunakan kosakata yang sudah diberikan oleh bagian bahasa setiap harinya. 5) Santri belum mampu memahami informasi yang diumumkan oleh bagian bahasa.

Adapun ungkapan secara lisan Ta'bīr Safāhī yaitu latihan membuat karangan secara lisan yang bertujuan untuk mengembangkan kemampuan pelajar dalam mengutarakan pikiran dan perasaannya. ${ }^{11}$ Maka untuk dapat melatih peserta didik agar cakap dalam berbicara bahasa Arab harus melalui Ta'bìr Safāhī.

Sedangkan pada dasarnya penerapan maharah istima ini belum diajarkan di tingkatan Santriwan santriwati SMP Pondok Modern AlAqsha Santri hanya sebatas mengetahui dasar-dasarnya saja.

Terkait Maharah Qiraah Santri: 1) Santri hanya sebatas membaca namun belum mampu memahami secara mendalam. 2) Siswa belum mampu membaca dengan baik sehingga sulit untuk membuat kesimpulan dan inti dari pelajaran yang dipelajari. 3) Santri membaca hanya ketika ujian saja. Berbentuk hafalan, tugas, ujian, ulangan, evaluasi pembelajaran.

Berdasarkan hasil analisis tersebut dapat disimpulkan bahwa dalam ranah Maharah Kalam, siswa belum dapat menggunakan bahasa arab dengan baik secara kaidah dalam berbicara. Adapun dalam rama maharah qira'ah siswa belum mampu menceritakan kembali isi bacaan khususnya dalam pelajaran dirasah islamiyah. Dan dalam ranah maharah istima' siswa masih belum bisa menangkap percakapan bahasa arab dan mengungkapkan isi percakapan tersebut. Sedangkan dalam maharah kitabah siswa masih belum bisa membuat paragraf dengan baik.

${ }^{10}$ Ahmad Izzan, Metodologi Pembelajaran Bahasa Arab (Bandung: Humaniora, 2011), h. 116.

${ }^{11}$ Izzan, h. 146. 


\section{Simpulan}

Berdasarkan rangkaian pembahasan yang telah dilakukan, penelitian ini menyimpulkan bahwa: 1) Pelaksanaan program kebahasaan yang dilakukan oleh lembaga pengembangan bahasa SMP Plus Al-Aqsha yang terdiri dari perencanaan, pengorganisasian, pelaksanaan, kontrol, dan evaluasi belum maksimal dilaksanakan. 2) Faktor pendukung pelaksanaan program kebahasaan ini adalah disiplinnya para pengajar bahasa dalam berbahasa, faktor penghambatnya adalah bebasnya bahasa yang digunakan antara siswa dengan para pedagang. 3) Kemampuan keterampilan berbahasa Arab siswa di SMP Plus Al Aqsha belum cukup baik karena pelaksanaan program belum maksimal. Penelitian ini diharapkan dapat menjadi rujukan dan bahan evaluasi bagi lembaga pengembangan bahasa yang terdapat di SMP Plus Al-Aqsha Jatinangor. Hasil penelitian ini menyarankan kepada lembaga pengembangan bahasa untuk mempertegas peraturan yang sudah berlaku terutama tentang konsistensi penggunaan bahasa dengan para guru dan wali santri yang tidak bisa berbahasa Arab dan Inggris untuk menggunakan bahasa Indonesia yang baik. Penelitian ini memberikan rekomendasi kepada peneliti selanjutnya yang akan mengkaji keterampilan berbahasa Arab agar lebih fokus pada evaluasi peserta didik terhadap Maharah Qiraah, Kalam, Istima' dan Kitabah. 


\section{Daftar Pustaka}

Al-Fauzan, Abdurrahman Ibrahim. Idha'at li Mu'allimi Lughah Arabiyah li Ghair Nathiqin Biha. Riyadh: Al-Arabiyyah Li Al-Jami', 2011.

Fatoni, Ahmad. "Arabic Learning for Academic Purposes.” Izdihar : Journal of Arabic Language Teaching, Linguistics, and Literature 2, no. 2 (2019): 149-64. https://doi.org/10.22219/jiz.v2i2.10096.

Hermawan, Acep. Metodologi Pembelajaran Bahasa Arab. Bandung: Remaja Rosdakarya, 2011.

Isqolaliyah, Farkha. "Pembelajaran Bahasa Arab di Tarbiyyah Hifdhul Ghulam Wal Banat (THGB) Pondok Pesantren 'Majma'al Bahrain' Siddiqiyah Ploso Jombang." Skripsi - Universitas Negeri Malang 0, no. 0 (26 September 2012). http://karya-ilmiah.um.ac.id/index.php/sastraarab/article/view/22507.

Izzan, Ahmad. Metodologi Pembelajaran Bahasa Arab. Bandung: Humaniora, 2011.

Rizal, Yanuar, Adelina Hasyim, dan Riswandi Riswandi. "Program Pembelajaran Bahasa Arab Di Madrasah Aliyah.” Jurnal Teknologi Informasi Komunikasi Pendidikan 5, no. 1 (2017). http://jurnal.fkip.unila.ac.id/index.php/JTP/article/view/11986.

Shodiq, Mohammad Amar. "Analisis Kebijakan Pengembangan Program Pembelajaran Bahasa Arab Di Boarding School Madrasah Aliyah Negeri Ciawigebang Kuningan Jawa Barat.” Thesis, UIN Sunan Kalijaga, 2016. http://digilib.uin-suka.ac.id/22645/.

Sutarjo, J., dan Albarra Sarbaini. "Proporsi Pengajaran Bahasa Arab Di Pondok Pesantren Ditinjau Dari Aspek Tipologi." An Nabighoh: Jurnal Pendidikan Dan Pembelajaran Bahasa Arab 21, no. 01 (2019): 1-19. https://doi.org/10.32332/an-nabighoh.v21i01.1254.

Umam, Islahel, Moh Hasin, dan Zakiyah Arifa. "Manajemen Pengorganisasian Program Kursus Markaz Bahasa Arab Darul Lughah Waddirasat Islamiyah." An Nabighoh: Jurnal Pendidikan Dan Pembelajaran Bahasa Arab 21, no. 01 (2019): 43-60. https://doi.org/10.32332/annabighoh.v21i01.1376. 